http://doi.org/10.11646/zootaxa.4161.3.9

http://zoobank.org/urn:lsid:zoobank.org:pub:2307EE18-2B28-472E-95CE-C0E2B6D07871

\title{
Description of the immature stages and new host plant records of Deois (Deois) mourei (Berg) (Hemiptera: Cercopidae), a species newly recorded from Argentina and Paraguay
}

\author{
ALVARO FOIERI ${ }^{1,4}$, ANA M. MARINO DE REMES LENICOV ${ }^{2} \&$ EDUARDO G. VIRLA $^{1,3}$ \\ ${ }^{1}$ CONICET - PROIMI Biotecnología, División Control Biológico, Av. Belgrano \& Pje. Caseros (4000) S.M. de Tucumán, Argentina. \\ E-mail: afoieri@conicet.gov.ar \\ ${ }^{2}$ CONICET - Div. Entomología, Facultad de Ciencias Naturales y Museo de La Plata, Paseo del Bosque s/n (1900) La Plata, \\ Argentina.E-mail: marinoremes@gmail.com \\ ${ }^{3}$ CONICET - Fund. M. Lillo, Inst. de Entomología, M. Lillo 251 (4000) S.M. de Tucumán, Argentina. E-mail: evirla@hotmail.com \\ ${ }^{4}$ Corresponding author
}

\begin{abstract}
Deois (Deois) mourei Cavichioli \& Sakakibara (Hemiptera: Cercopidae) is recorded for the first time from Argentina and Paraguay. The eggs and immature stages of the species are described and illustrated; the main characters that distinguish instars are body size, color, number of flagellomeres, and number of tibial and metatarsomere spines. A key for identification of nymphs of $D$. (D.) mourei and a key to differentiate nymphs of the sympatric species D. (D.) mourei and Notozulia entreriana Berg are provided. In addition, a list of host plants of $D$. (D.) mourei in Argentina is given.
\end{abstract}

Key words: instar, nymph, key, Poaceae, Auchenorryncha

\section{Introduction}

Spittlebugs cause substantial economic damage to grass crops worldwide (Heinrichs \& Barrion, 2004), including sugarcane (Saccharum offinarum L.) (Rodman \& Miller, 1992), maize (Zea mays L.) (Peck, 2002) and pasture grasses (Pires et al., 2000; Holmann \& Peck, 2002). Diverse genera of Cercopidae, like Aeneolamia, Mahanarva, Zulia, Notozulia, Prosapia and Deois spp. are considered a serious threat for forage in South America, causing up to a 70\% reduction in pasture yields in infested areas (Sanz, 1997; Thompson, 2004; Leite et al., 2005), particularly to the extensively planted genus Brachiaria (Lapointe \& Sonoda 2001).

The sap sucking spittlebugs have a wide host plant range in the monocots (Guagliumi 1957; Fewkes 1969; Souza \& Nilakhe 1985). They cause damage by mechanical feeding, by the physiological effects of saliva, and by facilitating the entry of microorganisms (Macedo et al., 2003). Despite their importance, there is a significant lack of information on various biological aspects of these insects. For example, in South America the immature stages have been described only in Kanaima fluvialis, Aeneolamia reducta and Notozulia entreriana (Cavichioli, 1987; Peck, 2002; Foieri et al., 2016).

The South American genus Deois was created by Fennah (1949) with Cercopis terrea Germar as the type species. Fennah (1953) reviewed the genus and divided it into three subgenera: Deois (Deois), Deois (Orodamnis) and Deois (Pandisia). Sakakibara (1979) added two subgenera to the genus: Deois (Acanthodeois) and Deois (Fennahia). Ferreira da Costa \& Sakakibara (2002) narrowed the scope of the genus, upgrading the subgenus Orodamnis to generic status. Currently, the genus contains 22 species in four subgenera (Carvalho \& Webb, 2005).

Deois (D.) mourei was originally described by Cavichioli \& Sakakibara in 1993 on the basis of specimens collected from some southern localities in Brazil. Except for some sporadic taxonomic studies (Sakakibara, 1979; Sakakibara \& Cavichioli, 1993), knowledge of this species is still insufficient. Recent work by the authors revealed that $D$. (D.) mourei is very frequent in northern Argentina, but its nymphs had not yet been described and therefore 
they could be easily confused with another very common and abundant sympatric species, Notozulia entreriana (Berg). Our studies on $D$. (D.) mourei have provided the opportunity to describe and illustrate the immature stages, to build a key for differentiation of nymphal instars, and to enlarge the knowledge of it distribution and host plants.

\section{Material and methods}

A colony of $D$. (D.) mourei was established during early summer 2015 with field-captured adults in San Miguel de Tucumán (Argentina) (26 $47^{\circ} 48.50^{\prime} \mathrm{S} 65^{\circ} 18^{\prime} 37.31$ ”W, $592 \mathrm{~m}$.asl). They were brought to the laboratory and placed in breeding cages in a greenhouse exposed to natural conditions (February to March 2015, average temperature $\left.=26^{\circ} \mathrm{C}\right)$, with natural photoperiod. Breeding was carried out in aluminum rearing cages $(50 \times 50 \times 50$ $\mathrm{cm}$ ) containing six healthy potted "slender pigeon grass" plants [Setaria parviflora var "parviflora" (Poir.) Kerguélen, Poaceae] (pots of $6.3 \mathrm{dm}^{3}$ ); every side but the base was closed by nylon mesh cloth, for aeration.

Individual females were transferred to polyethylene-terephtalathe cylindrical oviposition cages $(35 \mathrm{~cm}$ high, $18 \mathrm{~cm}$ diameter) placed over blades of Slender pigeon grass grown in pots. The females were allowed to oviposit for $24 \mathrm{hrs}$, then transferred to other potted host plants. Exposed plants were observed daily to determine nymphal hatching and the occurrence of molts. Some of the eggs obtained were separated for description and photography.

Ten nymphs of each instar were preserved in $70 \%$ ethyl alcohol. Each specimen was cleared in cold $10 \% \mathrm{KOH}$ solution and fixed in Faure's medium (distilled water, $50 \mathrm{~g}$; gum arabic (clear crystals), $50 \mathrm{~g}$; chloral hydrate, 200 $\mathrm{g}$; and glycerin, $20 \mathrm{~g}$ ) for microscopic examination and illustration. The first instar nymph is described in detail; only major changes that differ from the previous instar nymph are highlighted in the later stages. Measurements, average and range are given in millimeters and taken from specimens at $24-48 \mathrm{hrs}$ after molting. Drawings were made with a Zeiss stereoscopic microscope with a camera lucida and with a Leitz-Westzlar microscope using an adapted RRID 18 HD digital camera. Morphological terminology follows Cavichioli $(1987,1988)$ and Liang and Fletcher (2002).

Information on distribution was obtained from the study of specimens housed in entomological collections of the Facultad de Ciencias Naturales y Museo (MLP) (La Plata, Buenos Aires- Argentina) and the Fundación Miguel Lillo (IFML) (San Miguel de Tucumán, Tucumán- Argentina), and from field-captured specimens collected from diverse localities in Argentina and preserved in 70\% ethyl alcohol. Most of the specimens were obtained by sweeping, using entomological nets, from diverse crops, forage plots and/or surrounding vegetation, both in human modified and pristine environments. In many instances, the nymphs were collected with their host plant and moved to the laboratory until they reached the adult stage in order to confirm specific identity.

\section{Results and discussion}

Eggs. L: $0.70 \mathrm{~mm}$ and $\mathrm{W}: 0.29 \mathrm{~mm}$. Eliptical, very similar to the eggs of Notozulia entreriana (Berg) and practically impossible to differentiate between them.

Color pale yellow when first laid, changing to a deeper yellow or orange after a few days. During embryonic development, the anterior surface shows a darker area corresponding to the operculum. After approximately 4-6 days (Foieri, personal observation), it is possible to distinguish red eyespots in the anterior portion of the egg and two orange spots corresponding to the mycetoma.

First instar nymph (Figs. 1, 6, 11). Body length $1.52 \mathrm{~mm}(1.44-1.57 \mathrm{~mm})$; body width $0.45 \mathrm{~mm}(0.40$ $0.48 \mathrm{~mm})$; head length $0.26 \mathrm{~mm}(0.25-0.27 \mathrm{~mm})$; head width $0.33 \mathrm{~mm}(0.32-0.34 \mathrm{~mm})$; eye length $0.04 \mathrm{~mm}$; postclypeus width $0.28 \mathrm{~mm}(0.28-0.30 \mathrm{~mm})$; antennal total length $0.21 \mathrm{~mm}(0.20-0.21 \mathrm{~mm})$; pronotum length 0.14 $\mathrm{mm}(0.12-0.15 \mathrm{~mm})$.

General color light yellowish with two distinctive orange spots on each side of the abdomen, corresponding to the mycetoma, which are clearly observed in live specimens, red eyes. Head subcuadrangular, a little wider than long (1:0.8); eyes globose. Antennae inserted in antennal foveae at the side of the postclypeus, with inconspicuous supra-antennal ledge, flagellum with four flagellomeres (Fig. 6). Postclypeus globose, inflated, of convex profile, anteclypeus triangular, slightly separated from the postclypeus. Rostrum with 3 segments, reaching base of coxa III. Pronotum rectangular, wider than long (1.1:1), meso- and metanotum subrectangular, meso- plus metanotum 
2X longer than pronotum. Wingpads not evident. Metatibiae without lateral spines, with two apical spines; metatarsi with two tarsomeres; two apical plantar spines in the basal tarsomere (Fig. 11). In ventral view, abdomen with a longitudinal groove limited for laterals projections like-quadrangular plates formed from each sternal segment.
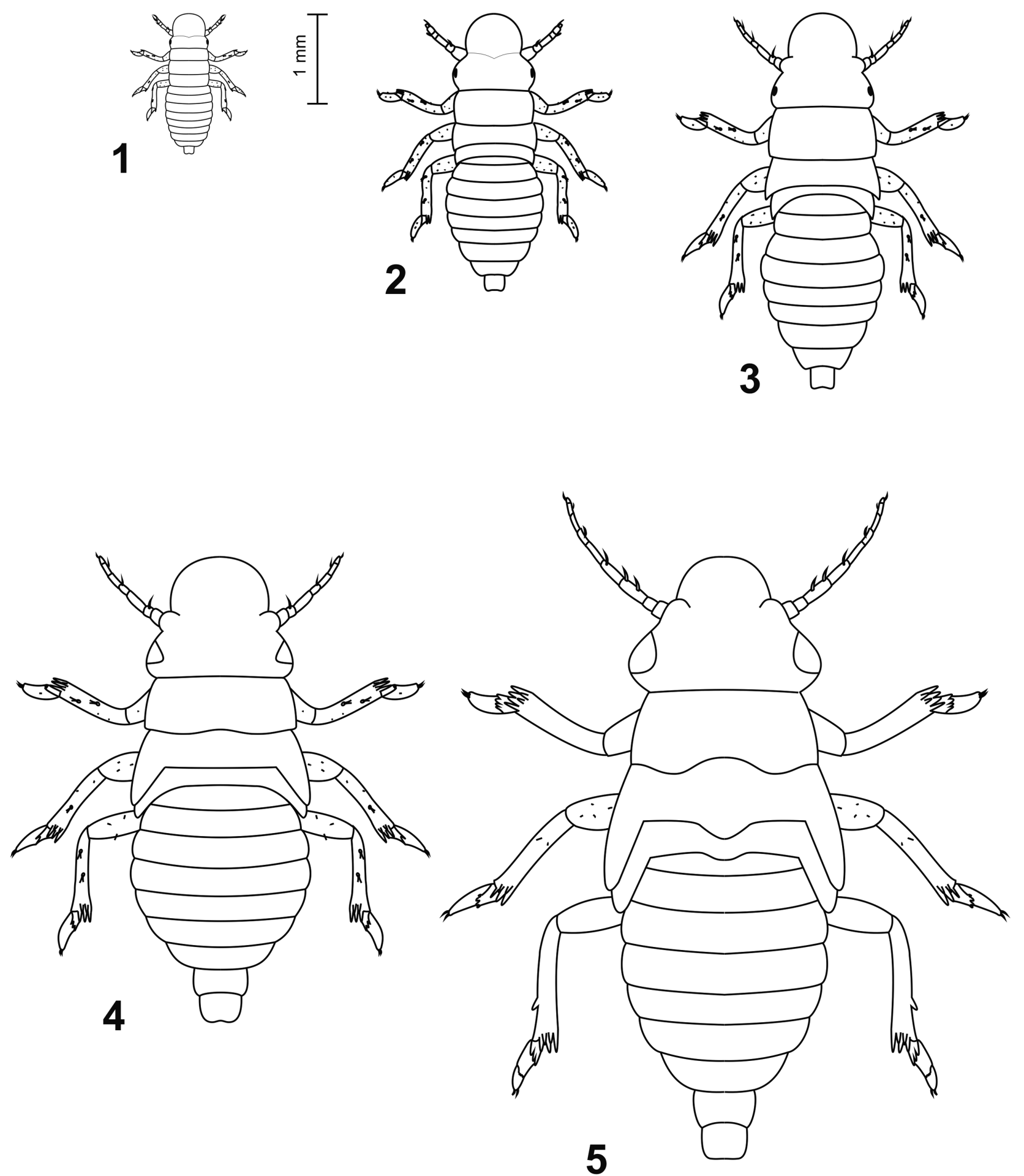

FIGURES 1-5. Immature stages of Deois (Deois) mourei in dorsal view: (1) First instar, (2) Second instar, (3) Third instar. (4) Fourth instar. (5) Fifth instar. Scale bar $=1 \mathrm{~mm}$.

Second instar nymph (Figs 2, 7, 12). Body length $3.28 \mathrm{~mm}(3.05-3.80 \mathrm{~mm})$; body width $0.60 \mathrm{~mm}(0.59-0.65$ $\mathrm{mm})$; head length $0.59 \mathrm{~mm}(0.50-0.60 \mathrm{~mm})$; head width $0.65 \mathrm{~mm}(0.65-0.70 \mathrm{~mm})$; eye length $0.4 \mathrm{~mm}$; postclypeus 
width $0.47 \mathrm{~mm}(0.40-0.47 \mathrm{~mm})$; antennal total length $0.35 \mathrm{~mm}(0.32-0.36 \mathrm{~mm})$; pronotum length $0.32 \mathrm{~mm}(0.29$ $0.35 \mathrm{~mm})$.

Coloration similar to that of the first instar. Postclypeus globose with lateral grooves strongly marked. Pronotum rectangular, wider than long (1.5:1). Meso- plus metanotum subequal to pronotum length, posterior margins of mesonotum straight, with the lateral angles slightly projected laterally. Wingpads slightly evident. Metatibiae with four apical spines. Metatarsi with three apical spines in the basal tarsomere and two spines in the middle of the plantar surface of the second tarsomere (Fig. 12). Abdomen similar in morphology to first instar.

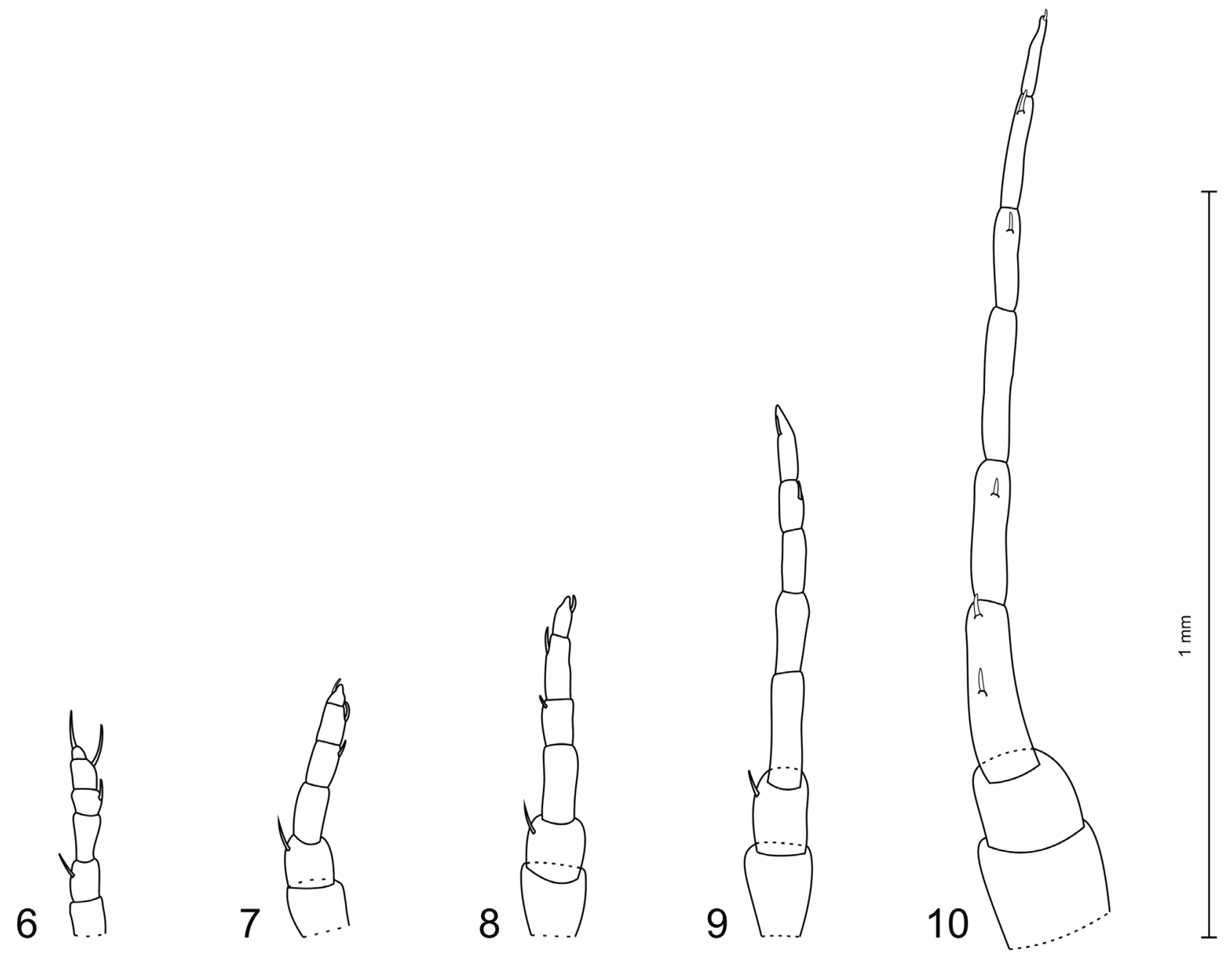

FIGURES 6-10. Antennae of Deois (Deois) mourei nymphal instars. (6) First instar. (7) Second instar. (8) Third instar. (9) Fourth instar. (10) Fifth instar. Scale bar $=1 \mathrm{~mm}$.

Third instar nymph (Figs 3, 8, 13). Body length $4.34 \mathrm{~mm}(4.10-4.60 \mathrm{~mm})$; body width $0.92 \mathrm{~mm}(0.92-1.10$ $\mathrm{mm})$; head length $0.72 \mathrm{~mm}(0.70-0.79 \mathrm{~mm})$; head width $0.85 \mathrm{~mm}(0.83-0.90 \mathrm{~mm})$; eye length $0.05 \mathrm{~mm}$; postclypeus width $0.59 \mathrm{~mm}(0.56-0.61 \mathrm{~mm})$; antennal total length $0.46 \mathrm{~mm}(0.46-0.50 \mathrm{~mm})$; pronotum length 0.46 $\mathrm{mm}(0.43-0.48 \mathrm{~mm})$.

General color similar to second instar but head and thorax darker. Supra-antennal ledge reaching antennal base, flagellum with four flagellomeres, the last three flagellomeres with apical single trichoid sensilla (Fig. 8). Postclypeus inflated with slightly marked median carina. Pronotum rectangular, wider than long (1.6:1), with the lateral angles slightly projected laterally, meso and metanotum with posterior margin sinuate on each side, slightly projected laterally. Wingpads evident, mesonotal wingpads reaching half of the metanotal wingpad, which reach the first abdominal segment. Metatibiae with seven apical spines. Metatarsi with four apical spines in the basal tarsomere and two spines in the middle of the plantar surface of the second tarsomere (Fig. 13). Abdomen similar to earlier instars.

Fourth instar nymph (Figs 4, 9, 14). Body length $5.26 \mathrm{~mm}$ (5.20-5.60); body width $1.80 \mathrm{~mm}$ (1.75-2.00); 
head length $0.85 \mathrm{~mm}(0.78-0.98 \mathrm{~mm})$; head width $1.35 \mathrm{~mm}(1.33-1.60 \mathrm{~mm})$; eyes length $0.15 \mathrm{~mm}$; postclypeus width $0.85 \mathrm{~mm}(0.80-0.91 \mathrm{~mm})$; antennal total length $0.73 \mathrm{~mm}(0.73-0.80 \mathrm{~mm})$; pronotum length $0.88 \mathrm{~mm}(0.70$ $0.90 \mathrm{~mm})$.

Head subtriangular, wider than long (1:0.7); eyes triangular. Antennal flagellum with five flagellomeres (Fig. 9). Anteclypeus markedly separated from postclypeus by an evident suture. Pronotum rectangular, wider than long (1.90:1), with posterior margin slightly sinuate. Meso- and metanotum with posterior margin slightly excavated; meso- plus metanotum $2 \mathrm{X}$ longer than pronotum length in midline. Wingpads lobate darkened, more developed, mesonotal wingpads slightly longer than pronotum (1:0.6), metanotal wingpads almost reaching the third abdominal segment. Metatibiae with eleven apical black-tipped spines. Metatarsi with six apical spines on the basal tarsomere (Fig. 14). Abdomen with genital plates evident in both sexes.
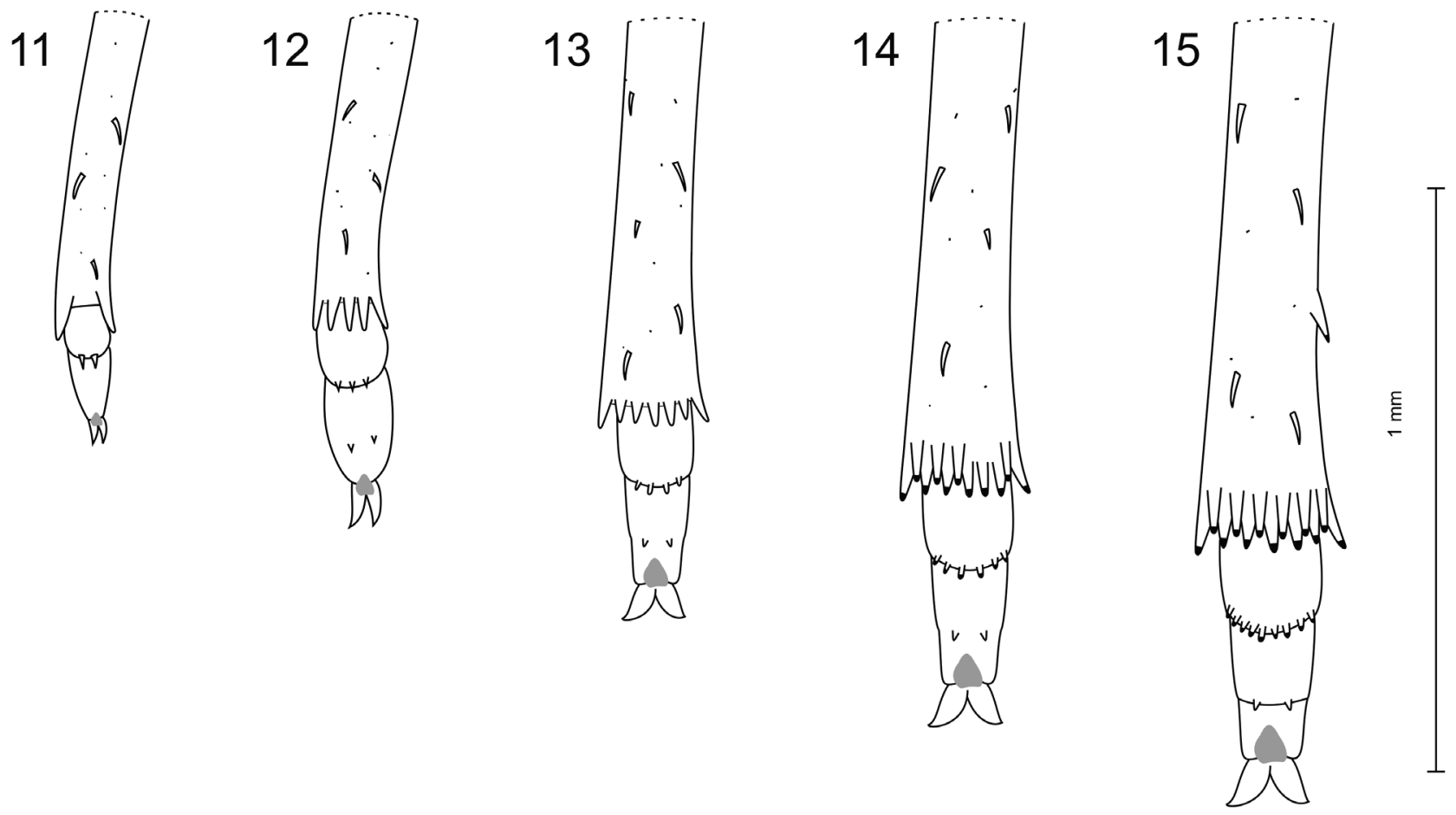

FIGURES 11-15. Apical portion of tibiae and tarsi of immature stages of Deois (Deois) mourei (11) First instar. (12) Second instar. (13) Third instar. (14) Fourth instar. (15) Fifth instar. Scale bar= $1 \mathrm{~mm}$.

Fifth instar nymph (Figs 5, 10, 15). Body length $6.84 \mathrm{~mm}(6.80-7.10 \mathrm{~mm})$; body width $2.5 \mathrm{~mm}(2.5-3.15$ $\mathrm{mm})$; head length $1.05 \mathrm{~mm}(0.95-1.10 \mathrm{~mm})$; head width $2.10 \mathrm{~mm}(2.00-2.20 \mathrm{~mm})$; eye length $0.32 \mathrm{~mm}$; postclypeus width $1.05 \mathrm{~mm}(0.95-1.10 \mathrm{~mm})$; antennal length $1.31 \mathrm{~mm}(1.30-1.33 \mathrm{~mm})$; pronotum length $0.92 \mathrm{~mm}$ (0.90-1.00 mm).

Head wider than long (1:0.6). Supra-antennal ledge well developed reaching middle of the first antennal segment, with rounded anterior margin. Antennal flagellum with six flagellomeres (Fig. 10), with celoconic sensilla dispersed on the basal flagellomere. Pronotum rectangular, $2 \mathrm{X}$ wider than long, with posterior margin sinuate. Meso- plus metanotum about $3 \mathrm{X}$ length of pronotum, both with convex posterior margin. Wingpads more developed, mesonotal wingpads longer than pronotum (1.4:1), metanotal wingpads almost reaching third abdominal segment. Metatibiae with one lateral black-tipped spine and thirteen apical black-tipped spines. Metatarsi with three tarsomeres, nine apical black-tipped spines on the basal tarsomere and two apical spines on the second tarsomere (Fig. 15). Abdomen similar to earlier instars with genital plates on the eighth and ninth segment more developed, allowing differentiation of the sexes. Female with two pairs of acute processes extending from juncture of sternites eight and nine; males with a single triangular plate-like structure on sternite IX with two short apical processes (Fig. 16). 

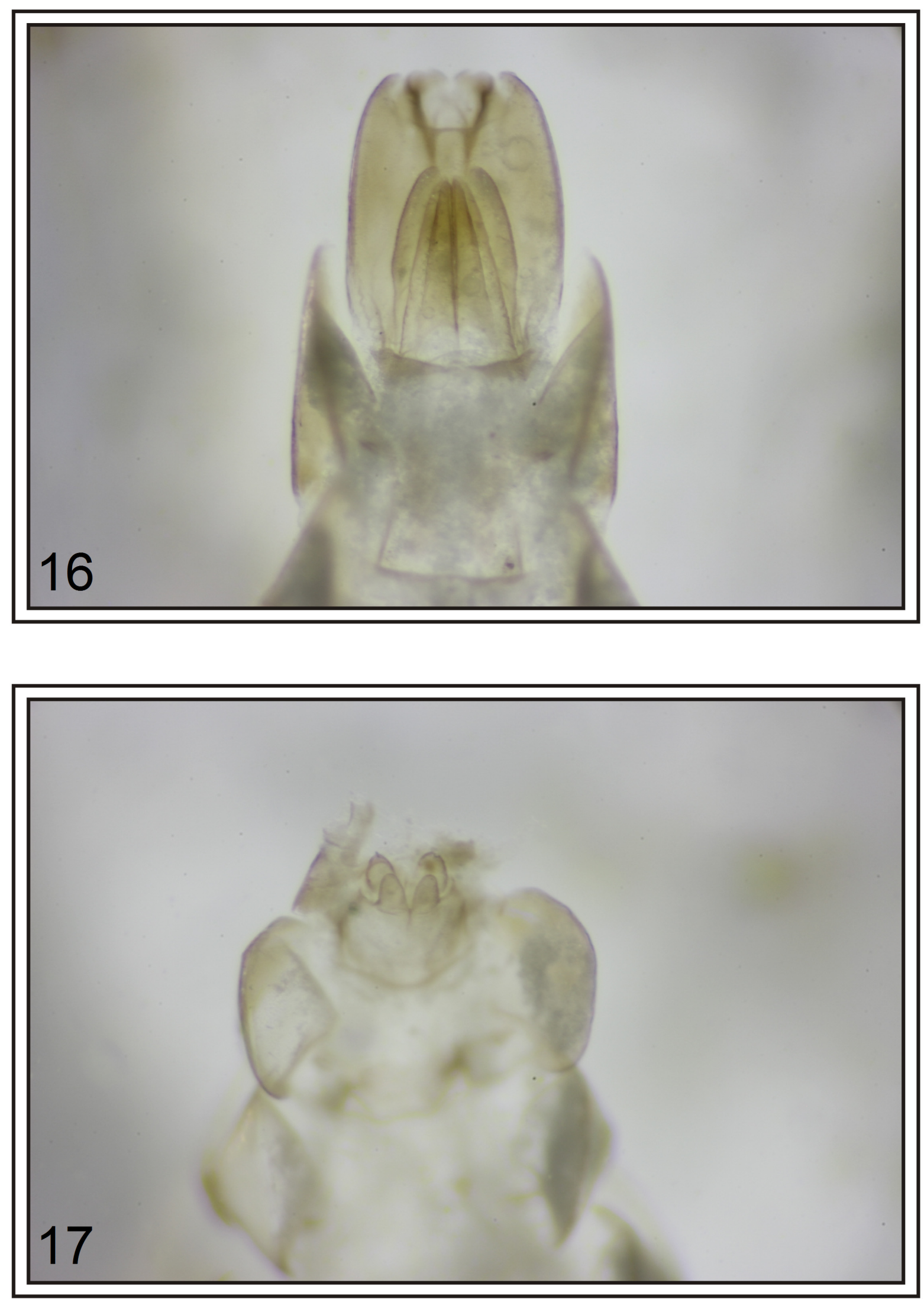

FIGURES 16-17. Apical portion of abdomen of Deois (Deois) mourei nymphal instars with genital plates on the eighth and ninth segment developed, allowing differentiation of the sexes. (16) Female with two pairs of acute processes extending from juncture of sternites eight and nine. (17) Male with a single triangular plate-like structure on sternite IX with two short apical processes. 


\section{Key to the nymphal instars of $D$. (D.) mourei}

1. Metatibiae and basal metatarsomere with 2 apical spines, respectively (Fig. 11). Wingpads not evident. Antennal flagellum

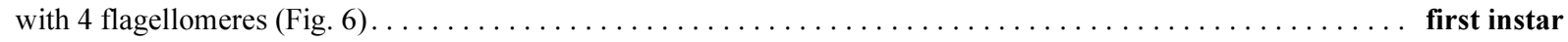
Metatibiae with 4 or more apical spines, basal metatarsomere with more than 3 apical spines. Wingpads evident. Antennal fla-

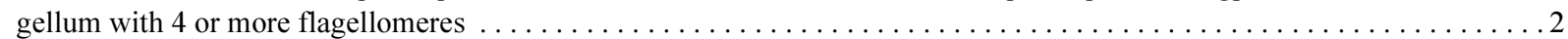
Metatibiae and basal metatarsomere with 4 and 3 apical spines, respectively (Fig. 12). Wingpads slightly evident. ........

second instar Metatibiae with 7 or more apical spines, basal metatarsomere with 4 or more apical spines; wingpads reaching the first abdom-

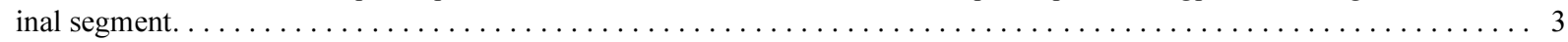

3. Metatibiae and basal metatarsomere with 7 and 4 apical spines, respectively (Fig. 13). Meso and metanotum slightly projected

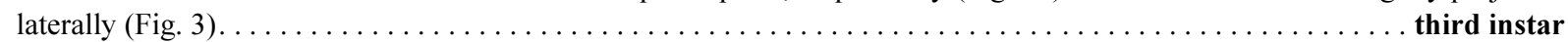
Metatibiae with 11 or more apical black-tipped spines, without or with one lateral spine; metatarsi with 2 or 3 tarsomeres, basal metatarsomere with 6 or more apical spines. Antennal flagellum with more than 4 flagellomeres $\ldots \ldots \ldots \ldots \ldots \ldots$

4. Metatibiae with 11 apical black-tipped spines and without lateral spines, basal metatarsomere with 6 apical spines and two spines in the middle of the plantar surface at level the second tarsomere (Fig. 14). Antennal flagellum with 5 flagellomeres

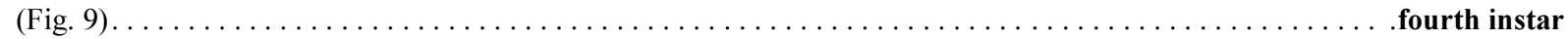

- Metatibiae with 13 apical black-tipped spines, with one lateral spine, metatarsi with 3 tarsomeres: basal tarsomere with 9 apical spines, second tarsomere with 2 apical spines (Fig. 15). Antennal flagellum with 6 flagellomeres (Fig. 10) ... fifth instar

\section{Key to differentiate the third to fifth nymphal instars of $D$. (D.) mourei and Notozulia entreriana (See Foieri et al. (2016) for a complete description of N. entreriana nymphs)}

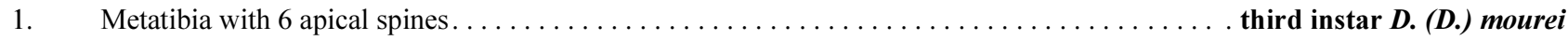

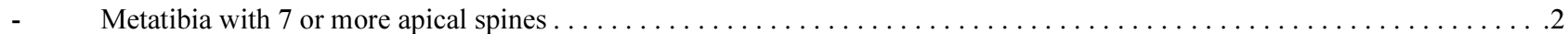

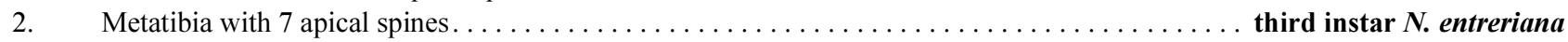

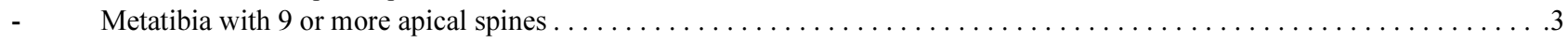

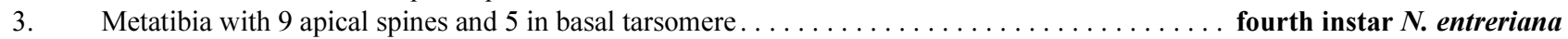

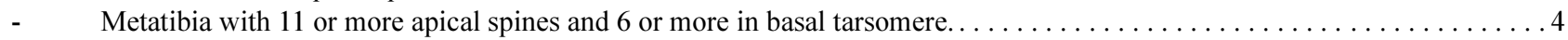

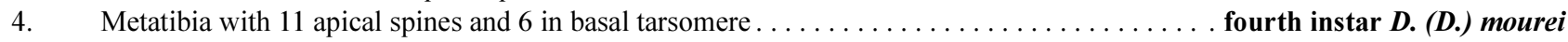

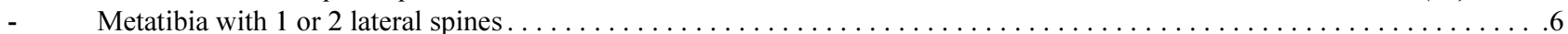

5. Metatibia 1 lateral spine and 13 apical black-tipped spines. First flagelomere with few celoconic sensilla and 2 single trichoid

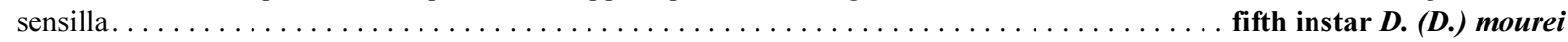
Metatibia whit 2 lateral spine and 10-13 apical black-tipped spines. First flagelomere with 11 celoconic sensilla and 1 apical

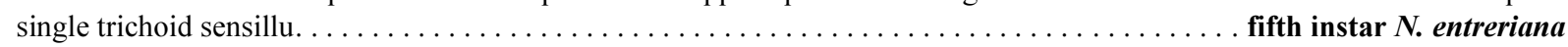

Remarks. The third to fifth nymphal instar of $D$. (D.) mourei can be reliably separated from those of $N$. entreriana that live in similar environments; although they are very similar because many characters are shared (colour, number of antennal flagellomeres, body and pronotum shape), other structures like the number of apical and lateral spines in the metatibia and basal tarsi and characters in the antenna permit separation of the species (Foieri et al., 2016).

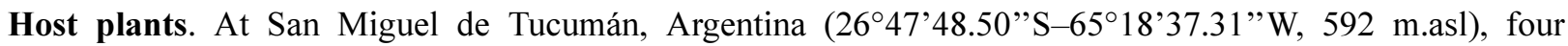
species of Poaceae were recorded as host plants: "Rhodes grass" (Chloris gayana var. epica), "Goose grass" (Eleusine indica (L.) Gaertn), "Marsh bristlegrass" (Setaria parviflora var. parviflora (Poir.) Kerguélen), and "Maize" (Zea mays L.). The first three are breeding and feeding host plants, but maize was only an adult host. We were not able to breed this species on it because newly emerged nymphs failed to develop. From field and laboratory observations $D$. (D.) mourei seems to be mostly associated with natural communities of grasses because it was rarely collected from crops. This species showed high specificity for $S$. parviflora when choosing a breeding host plant, differing from other species such N. entreriana and Deois (D.) knoblauchii (Berg), which are associated with a wide range of breeding and feeding host plants (Box, 1929; Foieri et al., 2016).

Distribution. The present study includes 189 specimens ( 82 males and 107 females) of $D$. (D.) mourei from Argentina and Paraguay, the first records from these countries. It documents a wide species distribution, mostly in the Paraná-Paraguay river basin (Argentina, Paraguay and southern Brazil) (Fig. 18), including 42 localities in 12 provinces (the southernmost distribution site is Buenos Aires city, $34^{\circ} 35^{\prime} \mathrm{S} 58^{\circ} 25^{\prime} \mathrm{W}, \approx 17 \mathrm{~m}$.asl). The species inhabits the subtropical region in locations ranging from 20 to $1765 \mathrm{~m}$.asl and occurs in the biogeographical provinces of Pampa, Yungas, Chaco, Parana Forest and Monte [following Morrone (2006)].

The distribution of $D$. (D.) mourei is coincident with $N$. entreriana, another very common spittlebug species 
(Foieri et al. 2015). The distribution of $D$. (D.) mourei in the region is comparable with that of its preferred host plant, Setaria parviflora, a grass widely distributed from the United States to southern Argentina and Chile (Rzedowski \& Rzedowski, 2004).
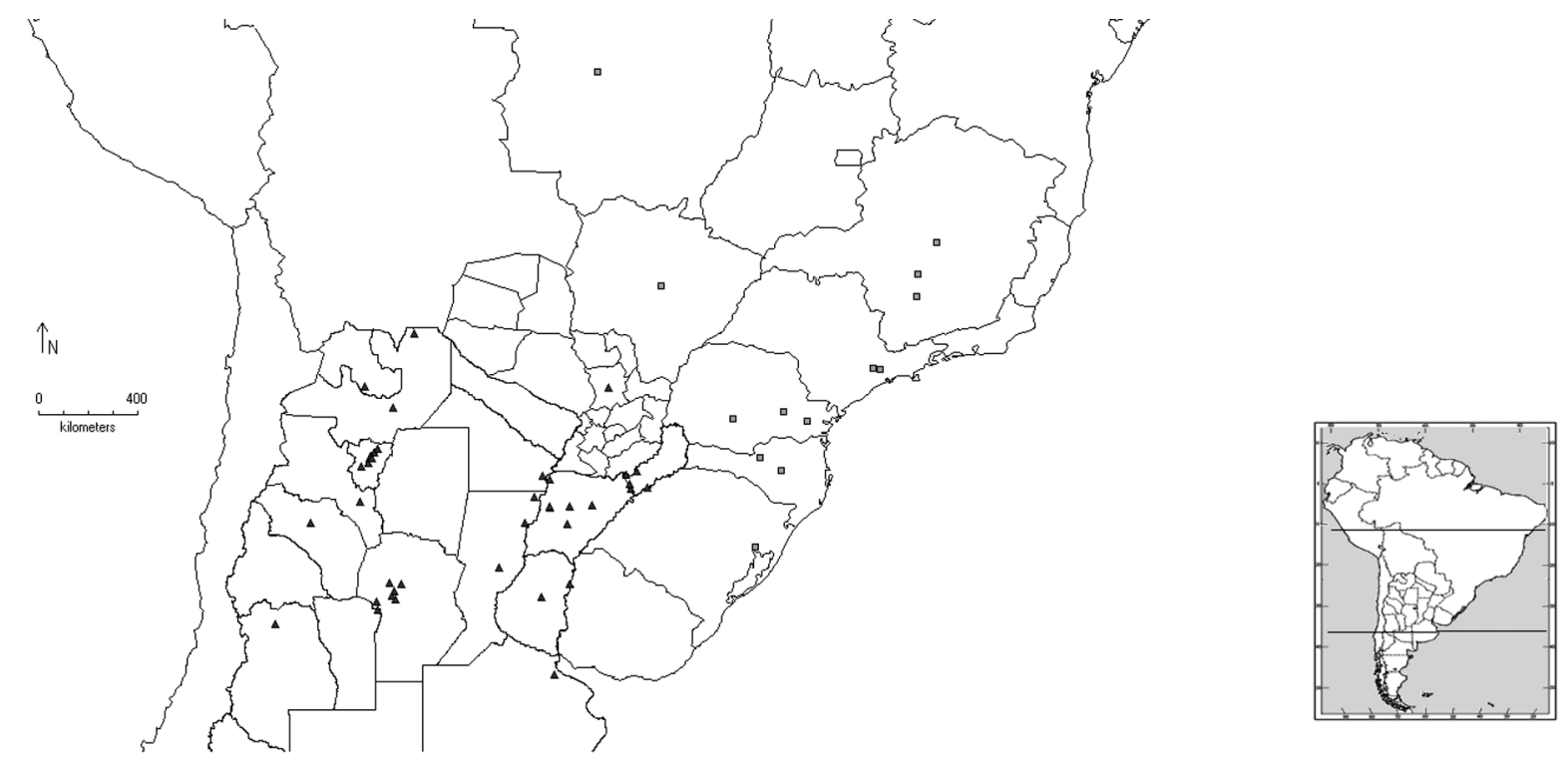

FIGURE 18. Distributon of Deois (Deois) mourei in Argentina, Paraguay and Brazil. (匹) Formerly known distribution records (Brazil). ( $\mathbf{\Delta})$ new records for Argentina and Paraguay.

Examined material. Field-captured specimens: ARGENTINA: SALTA: 19 , Cabeza de Anta (2455'96,3"S

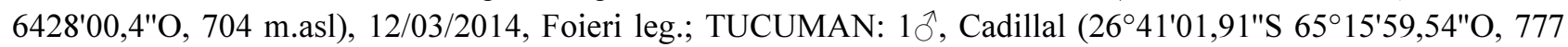

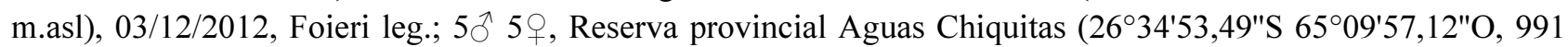
m.asl) 03/12/2012, Foieri leg.; 2 , , ruta provincial 307 (gauging station) $\left(27^{\circ} 05^{\prime} 58,6^{\prime \prime} \mathrm{S} 65^{\circ} 38^{\prime} 16,5^{\prime \prime} \mathrm{O}, 623 \mathrm{~m}\right.$.asl), 10/12/2012, Foieri leg.; $10{ }^{\lambda} 17$, , El Nogalito (2648'0,06"S 6528'19,60"O, 1040 m.asl), 07/02/2013, Foieri leg.; $5{ }^{\lambda}$ 9우, San Miguel de Tucumán (2648'36,56"S 6514'28,19"O, 464 m.asl), 09/02/2013, Foieri leg. CORRIENTES: $8 \overbrace{}^{\Uparrow} 12$, , Riachuelo (2734'52,31"S 5844'46,75"O, 61 m.asl), 29-31/10/2014, Virla leg.; $2 \AA 1$, Puente Pexoa

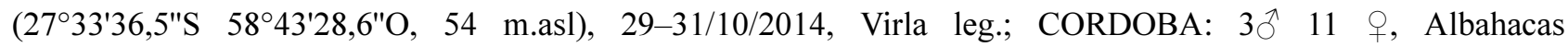
$\left(31^{\circ} 25^{\prime} 22,29^{\prime \prime} \mathrm{S} 64^{\circ} 08^{\prime} 28,86^{\prime \prime} \mathrm{O}, 382 \mathrm{~m}\right.$. asl), 03/04/2015, Virla leg.; $10^{\lambda} 1$ \% , San Agustin $\left(31^{\circ} 58^{\prime} 40,41^{\prime \prime S}\right.$

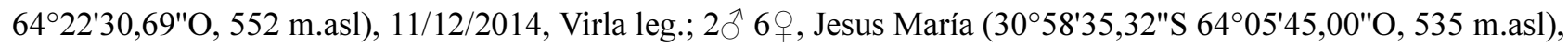
11/12/2014, Virla leg; 3ô 1ㅇ, Alpa Corral (32॰41'28,49"S 64²3'28,77"O, 862 m.asl), 03/04/2015, Virla leg.

Specimens hosted at MLP: ARGENTINA: MISIONES: 2 \% , San Ignacio $\left(27^{\circ} 15^{\prime 2} 29,13^{\prime \prime} \mathrm{S} 55^{\circ} 32^{\prime} 07,30^{\prime \prime} \mathrm{O}, 153\right.$ m.asl), 08/12/1941, Biraben-Bezzi leg.; 2 , , Posadas (27²2'48,97"S 5554'20,79"O, 116 m.asl), ?/01/1942, Bosq leg.; 2 , , Pindapoy $\left(27^{\circ} 74^{\prime} 04,00^{\prime \prime S} 55^{\circ} 78^{\prime} 04,00^{\prime \prime} \mathrm{O}, 116\right.$ m.asl), 14/12/1941, Biraben-Bezzi leg. CORRIENTES: $8{ }^{\lambda}$

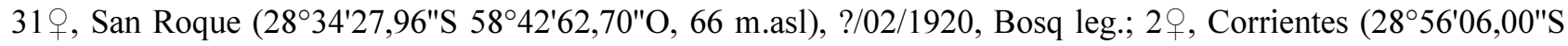

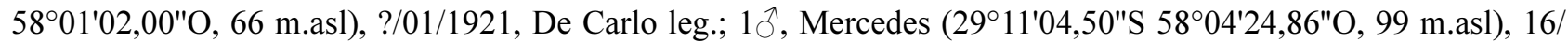

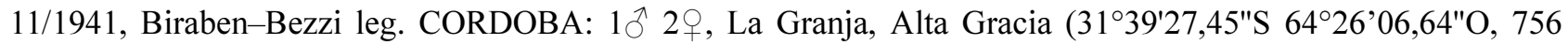
m.asl), ?/01/1938, Bruch leg.; 3q, Tanti $\left(31^{\circ} 21^{\prime} 17,32^{\prime \prime} \mathrm{S} 64^{\circ} 35^{\prime} 17,32^{\prime \prime} \mathrm{O}, 860 \mathrm{~m} . \mathrm{asl}\right) ; 40^{\hat{0}} 9 \circ$, Cabana $\left(31^{\circ} 13^{\prime} 00,48^{\prime \prime} \mathrm{S} 64^{\circ} 21^{\prime} 59,93^{\prime \prime} \mathrm{O}, 860 \mathrm{~m}\right.$.asl), 27/11/1925. SANTA FE: 4 우, Reconquista $\left(28^{\circ} 08^{\prime} 46,58^{\prime \prime} \mathrm{S} 59^{\circ} 38^{\prime} 37^{\prime \prime O}\right.$, 42 m.asl), 26/12/1939, Biraben-Bezzi leg.; 2ᄋ, El Rabón (28¹3'16,04"S 59¹6'04,68"O, 53 m.asl), 27/11/1939, Biraben-Bezzi leg.; 1 ${ }^{\circ}$, San Justo $\left(30^{\circ} 47^{\prime} 23,02^{\prime \prime S} 60^{\circ} 35^{\prime} 36,19^{\prime \prime} \mathrm{O}, 59\right.$ m.asl), 21/11/1939, Biraben-Bezzi leg.

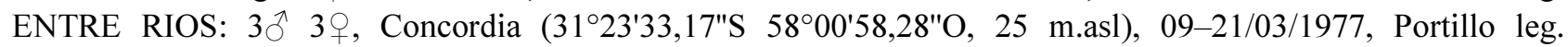
BUENOS AIRES: 2 \% , Buenos Aires (343ำ $09,06^{\prime \prime} \mathrm{S} 58^{\circ} 25^{\prime} 40,04^{\prime \prime} \mathrm{O}, 17$ m.asl), Bosq leg.

Specimens hosted at IFML: ARGENTINA: JUJUY: 3 $0^{\prime}$, Termas de Reyes $\left(24^{\circ} 11 ' 29,35^{\prime \prime S} 65^{\circ} 29^{\prime} 10,72^{\prime \prime} \mathrm{O}\right.$,

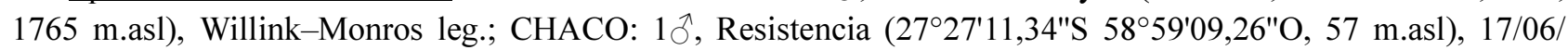

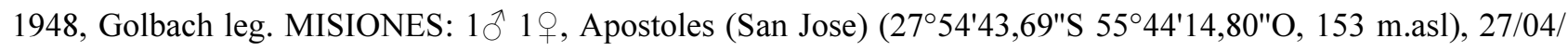

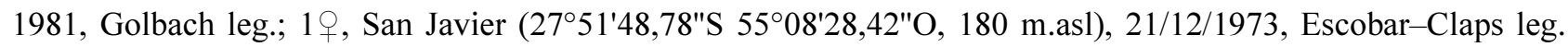

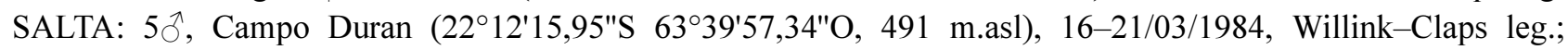
TUCUMAN: 2 ${ }^{\Uparrow}$, Horco Molle (2646'55,02"S 6519'52,46"O, 735 m.asl), ?/02/1960, Porter leg.; 1q, San Javier 


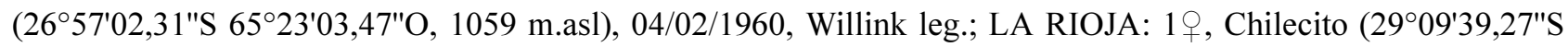

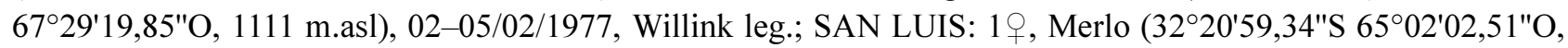
798 m.asl), 24/01/1958, Willink-Tonsic leg.; CORRIENTES: $20^{\lambda} 1$ 웅, Colonia Pellegrini $\left(28^{\circ} 31^{\prime} 59,90^{\prime \prime} \mathrm{S}\right.$

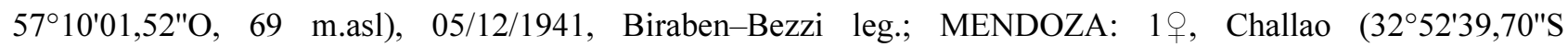
$68^{\circ} 45^{\prime} 05,56^{\prime \prime} \mathrm{O}, 697$ m.asl), 20/01/1982, Willink. leg.; CORDOBA: $3{ }^{\lambda} 8$ 웅, San Miguel (Yacanto de Calamuchita) $\left(32^{\circ} 03^{\prime} 16,08^{\prime \prime} \mathrm{S} 65^{\circ} 03^{\prime} 13,79^{\prime \prime} \mathrm{O}, 750 \mathrm{~m}\right.$.asl), ?/01/1958, Willink-Tonsic leg.; $50^{\wedge} 3$, , Yacanto a San Javier

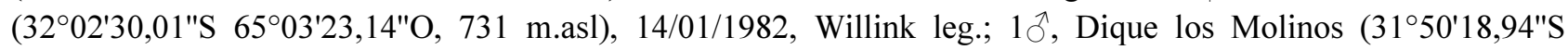
$\left.64^{\circ} 31^{\prime} 11,77^{\prime \prime O}, 807 \mathrm{~m} . a s l\right), ? / 01 / 1986$, Willink leg. ENTRE RIOS: $1 \delta^{\wedge} 2$, , Villaguay $\left(31^{\circ} 52^{\prime} 08,02^{\prime \prime} \mathrm{S}\right.$

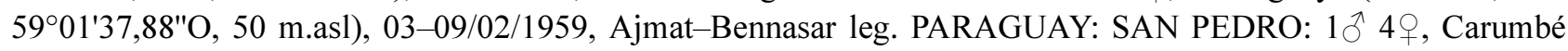
(2411'43,84"S 56³3'42,01"O, 190 m.asl), 28/01-10/03/1965, Golbach leg.

\section{Acknowledgments}

We thank Raul Foieri for graphics technical support. This study was supported by the Argentina National Research Council (CONICET), PIP $2013 \mathrm{n}^{\circ}$ 0222, and partially by the Fundación M. Lillo. A. Foieri is a CONICET fellowship holder.

\section{References}

Box, H.E. (1929) Una relación de nuestros conocimientos de la familia Cercopidae en la Argentina. Revista Industrial y Agrícola de Tucumán, 20 (1-2), 1-18.

Carvalho, G.S. \& Webb, M.D. (2005) Cercopid Spittlebugs of the New World (Hemiptera, Auchenorrhyncha, Cercopidae). Pensoft, Sofia, $271 \mathrm{pp}$.

Cavichioli, R.R. (1987) Sobre a biologia de Kanaima fluvialis (Lallemand, 1924) (Homoptera, Cercopidae). Revista Brasileira de Entomologia, 31 (1), 71-82.

Cavichioli, R.R. (1988) Estudo sobre a morfologia de Kanaima fluvialis (Lallemand, 1924) (Homoptera, Cercopidae). Revista Brasilera de Entomologia, 32 (3/4), 393-410.

Cavichioli, R.R. \& Sakakibara, A.M. (1993) Deois Fennah, Descrição de uma espécie nova e notas taxonômicas (Homoptera, Cercopidae, Tomaspidinae). Revista Brasileira de Zoologia, 10 (4), 747-750. http://dx.doi.org/10.1590/S0101-81751993000400019

Fennah, R.G. (1949) New genera and species of Neotropical Cercopoidea (Homoptera). Annals and Magazine of Natural History, 12 (1), 605-620.

Fennah, R.G. (1953) Revisionary notes on Neotropical Monecphorine Cercopoidea (Homoptera). Annals and Magazine of Natural History, 12 (6), 337-360. http://dx.doi.org/10.1080/00222935308654431

Ferreira da Costa, A.C. \& Sakakibara, A.M. (2002) Reestruturação do gênero Deois Fennah, desrição de um novo genero e de novas especies (Homoptera, Cercopidae, Tomaspidinae). Revista Brasileira de Entomologia, 46, 195-207. http://dx.doi.org/10.1590/S0085-56262002000200012

Fewkes, D.W. (1969) The biology of sugar cane froghoppers. In: Williams, J.R., Metcalfe, J.R., Mongomery, R.W. \& Mathes, R. (Eds.), Pests of Sugar Cane. Elsevier, Amsterdam, pp. 283-307

Foieri, A., Marino de Remes Lenicov, A.M. \& Virla, E.G. (2016) Descriptions of the immature stages and new host plant records of Notozulia entreriana (Berg) (Hemiptera: Cercopidae) pests of grasses in subtropical areas of the Americas. Zootaxa, 4103 (1), 54-62. http://dx.doi.org/10.11646/zootaxa.4103.1.5

Foieri, A., Virla, G.E. \& Marino De Remes Lenicov, A.M. (2015) New host plants records for the froghopper Notozulia entreriana (Hemiptera: Cercopidae) with new data on its occurrence in diverse ecological zones in Argentina. Revista de la Sociedad Entomologica Argentina, 74 (1-2), 79-84.

Guagliumi, P. (1957) Contribuciones al estudio de la candelilla de las gramíneas en Venezuela. III. Cuadro de distribución geográfica de las especies de Aeneolamia Fennah y sus plantas hospederas señaladas en Venezuela. Agronomia Tropical, 6, 165-194.

Heinrichs, E.A. \& Barrion, A.T. (2004) Rice-feeding Insects and Selected Natural Enemies in West Africa. Biology, Ecology, Identification. International Rice Research Institute, Los Banos \&WARDA, The Africa Rice Center, Abidjan, 242 pp.

Holmann, F. \& Peck, D.C. (2002) Economic damage of grassland spittlebugs (Homoptera: Cercopidae) in Colombia: A first approximation of impact on animal production in Brachiaria decumbens pastures. Neotropical Entomology, 31, $275-284$. http://dx.doi.org/10.1590/S1519-566X2002000200016

Lapointe, S. \& Sonoda, R.M. (2001) The effect of arthropods, disease, and nematodes on tropical pastures. In: Sotomayor-Rios, 
A. \& Pitman, W.D. (Eds.), Tropical Forage Plants: Development and use. CRC Press, Boca Raton, pp. 201-218.

Leite, L.G., Machado, L.A., Goulart, R.M., Tavares, F.M. \& Filho, A.B. (2005) Screening of entomopathogenic nematodes (Nemata: Rhabditida) and the efficiency of Heterorhabditis sp. against the sugarcane root spittlebug Mahanarva fimbriolata (Fabr.) (Hemiptera: Cercopidae). Neotropical Entomology, 34, 785-790. http://dx.doi.org/10.1590/S1519-566X2005000500010

Liang, A.-P. \& Fletcher, M. (2002) Morphology of the antennal sensilla in four Australian spittlebug species (Hemiptera: Cercopidae) with implications for phylogeny. Australian Journal of Entomology, 41, 39-44. http://dx.doi.org/10.1046/j.1440-6055.2002.00266.x

Macedo, N., Botelho, P.S.M. \& Campos, M.B.S. (2003) Controle químico da cigarrinha-da-raíz em cana-de-açúcar e impacto sobre as populações de artrópodes. STAB. Açúcar, Álcool e Subprodutos, Piracicaba, 21, 30-33.

Morrone, J.J. (2006) Biogeographic areas and transition zones of Latin America and the Caribbean Islands based on panbiogeographic and cladistic analyses of the entomofauna. Annual Review of Entomology, 51, 467-494. http://dx.doi.org/10.1146/annurev.ento.50.071803.130447

Peck, C.D. (2002) Distribucion y reconocimiento del salivazo de los pastos en la Costa Caribe de Colombia. Pasturas Tropicales, 24 (1), 4-15.

Pires, C.S.S., Sujii, E.R., Fontes, E.M.G., Tauber, C.A. \& Tauber, M.J. (2000) Dry-season dormancy in eggs of Deois flavopicta (Homoptera: Cercopidae): roles of temperature and moisture in nature. Environmental Entomology, 29, 714-720. http://dx.doi.org/10.1603/0046-225X-29.4.714

Rodman, D.H. \& Miller, D.J. (1992) Enzyme activities associated with salivary glands of the froghopper Eoscarta carnifex (F.) (Homoptera, Cercopidae): possible role of salivary catalase in phytotoxicity. Australian Journal of Zoology, 40, 365-370. http://dx.doi.org/10.1071/ZO9920365

Rzedowski, G. \& Rzedowski, J. (2004) Manual de malezas de la región de Salvatierra, Guanajuato. Flora del Bajío y de Regiones Adyacentes. Fascículo complementario XX. Instituto de Ecología, Pátzcuaro, 315 pp.

Sakakibara, A.M. (1979) Sobre algumas espécies brasileiras de Deois Fennah, 1948 (Homoptera, Cercopidae). Revista Brasileira de Biologia, 39 (1), 9-30.

Sanz, N.T. (1997) Checklist of Pests and Diseases of Selected Crops of Belize. Belize National Plant Protection Service, Ministry of Agriculture and Fisheries, Central Farm, Cayo District, $151 \mathrm{pp}$.

Souza, A.R.R. \& Nilakhe, S.S. (1985) Damage evaluation and chemical control of spittlebugs in rice crops. Anais da Sociedade Entomológica do Brasil, 14, 177-188.

Thompson, V. (2004) Associative nitrogen fixation, C4 photosynthesis, and the evolution of spittlebugs (Hemiptera: Cercopidae) as major pests of Neotropical sugarcane and forage grasses. Bulletin of Entomological Research, 94 (1), 189 200.

http://dx.doi.org/10.1079/ber2004293 